\title{
Community safety and repurposing the police before, during, and after a pandemic: Methodological notes
}

\author{
Ron Levi, ${ }^{*}$ Todd Foglesong, ${ }^{\dagger}$ and Matt Torigian ${ }^{\dagger}$
}

The text below is a lightly edited version of our response to a call for research proposals on COVID-19. We wrote it in early April 2020. We reproduce it here as a source of insight for how to think about stressors, strains, and possible changes to the role of the police. The proposal raises the issue of when police leaders explicitly must reckon with the future of policing in the aftermath of crises.

\section{INTRODUCTION}

Police leaders everywhere are saying that COVID-19 is a "game-changer," a shock to the system of public safety so great that it is causing them to "throw out the old rule books." "This is policy development at the speed of crisis," one police leader told us, with another saying he "hardly recognized" the organization he heads. But is it true? What kinds of changes are being wrought in policing, and how radical are they, really? Will the economic and social recovery from the COVID-19 pandemic require a redefinition of the role of the police in the production of safety and community well-being in our society? If so, what changes will the recovery need from policing now, and who will make them happen?

Maybe nothing will change in the end, and local police forces will respond reactively to infractions through the current paradigm of "law enforcement." Another possibility is that the recovery will require temporarily tethering parts of policing to public health needs, with police conscripted into epidemiological surveillance and vector isolation. A third possibility is that the public health recovery will necessitate the tethering of policing to the economic logic of social investment, through proactive harm reduction and social inclusion. Such a shift would involve the police taking directions from public health authorities rather than their chiefs.

Which possibility is more likely? Right now, the signs are mixed. Some police organizations are employing old ideas about how to preserve public order in crises-such as stern threats to punish disobedience. Others appear to be adapting ideas borrowed from public health about how to foster voluntary compliance with civic norms - through moral exhortation, anticipatory praise ("thank you for not thieving"), and carefully dosed interventions on suspected vectors (such as gangs or vulnerable groups). No one knows whether any strategy is working, or how to measure "working." And no one knows whether the police will revert to older criminal justice ideas about how to generate public safety before the pandemic and the recovery are over.

In other words, how would one know if policing is being "transformed" or "remade" in the sociological sense of these words? What kinds of changes in the thought style of policing, the organizational forms it takes, and the purposes to which its resources are put would indicate that policing is being transformed before our eyes in the course of responding to COVID? We expand on these through three research questions.

1. What strategies of policing during the pandemic and for the eventual recovery are being implemented, and where? Are police agencies focusing their resources on neighbourhoods and groups that are conventionally "high risk" for crime, or paying attention to needs in areas that are considered vectors for viral growth? What information about public health is guiding the deployment of scarce resources? Are projections of behavioural patterns drawn from street-level intelligence and officers' intuitions, or from statistical models from other agencies such as public health? Are police officers using old-school techniques of quarantine, isolation, and contact tracing, or distal technologies of messaging, nudging, and building voluntary compliance? What are the strategies, in other words, for community safety during COVID-19?

2. Are measurements about what is a good outcome or positive result in policing changing in the course of the pandemic and eventual recovery? Are the metrics of success in policing still tied to incidents and individuals involved in crime, or are they attached to trends and patterns in well-being at the level of population? Are headline-grabbing crimes being supplanted by statistical charts of harm, risk, and precaution?

Correspondence to: Ron Levi, Munk School of Global Affairs \& Public Policy, University of Toronto, The Observatory, 315 Bloor St W, Toronto, ON M5S OA7. E-mail: ron.levi@utoronto.ca

To cite: Levi, R., Foglesong, T., and Torigian M. (2020). Community safety and repurposing the police before, during, and after a pandemic: Methodological notes. Journal of Community Safety and Well-Being, 5(2), 75-78. https://doi.org/10.35502/jcswb.135

(C) Author(s) 2020. Open Access. This work is distributed under the Creative Commons BY-NC-ND license. For commercial re-use, please contact sales@sgpublishing.ca.

gg PUBLISHING Published by SG Publishing Inc. CSAA Official publication of the Community Safety Knowledge Alliance. 
3. Is what is "thinkable" in policing changing (Koehler, 2020)? Is police leadership changing to address the pandemic and support eventual recovery? Are the advice of public health experts and the principles of community well-being now guiding police operations, or are mandates and imperatives from criminal justice still ascendant? Are front-line officers being encouraged to clinically problem-solve and shape community dynamics?

These questions are crucial for addressing the COVID-19 pandemic. Research demonstrates that people engage in anticipatory behavioural change based on their impressions of police activity-and that collective beliefs about the reliability, trustworthiness, and helpfulness of the police influence whether people will reach out to them in times of crisis (Campeau, Levi, \& Foglesong, 2020; Hagan, McCarthy, Herdad, \& Chandrasekhere, 2018; Stein \& Levi, 2014; Desmond, Papachristos, \& Kirk, 2016). What police do will shape public behaviour, public health, and social order.

\section{METHODOLOGY}

The impossibility of in-person research during the pandemic and the challenges of capturing the attention of people and agencies may prohibit conventional empirical research on policing.

One research method we will use will involve analysis of statements, claims, and declarations of police leaders and elected officials about the role of police during COVID-19. Using text analysis software, including statistical topic models, we will collect and code media reports, press releases, and social media from ten police departments in Canada, the United States, the United Kingdom, and Israel (Toronto, Vancouver, Montreal; Cleveland, New York, Los Angeles; London, Manchester; Tel Aviv, Jerusalem). The resulting dataset will represent public-facing accounts of how pandemic policing is defined and practiced. It will also provide a bank of material to engage police leaders.

A second research method will involve the statistical analysis of administrative data on the deployment of police resources across three Canadian cities, especially the rates of dispatched "calls for service" for public order complaints and social hazards, as well as reports of violent offenses and property crime. We will analyze changes in the spatial patterns of deployment during the pandemic and contrast them with public health data about the incidence and prevalence of $\mathrm{CO}$ VID-19 infections. Do police activities in response to requests for help unrelated to property crime and violence overlap with epidemiological patterns? These data will represent how pandemic policing shifts Canadian police operations.

A third research method will consist of private interviews and small focus group discussions with police leaders, online, using a semi-structured interview protocol. These will be recorded and transcribed. We will shift to face-to-face interviews and focus groups if they become possible over the timeframe of the project. A transcript of group conversations will then form the foundation of short policy papers. We also expect some police leaders to be co-authors of these papers, which should make it more likely that the ideas and insights from the research will be acted upon.
The research team has extensive experience across these qualitative and quantitative methods, with extensive practitioner networks with police in Canada, the United States, and abroad.

\section{PANDEMIC POLICING AND RECOVERY POLICING}

Many social scientists and police executives believe that we are currently testing the limits of social order as well as policing. This is partly because there are unanswered questions about civil unrest and the likelihood of individuals to continue to abide by public health mandates to quarantine, self-isolate, or shelter in place (Briscese, Lacetera, Macis, \& Tonim, 2020). In addition, despite reports of reductions in violent crime during social isolation, we are witnessing increased reporting of domestic violence and child abuse (Carlson, 2020). Broad concern over the well-being of children prompted Prime Minister Trudeau, on 29 March 2020, to announce an additional \$7.5 million for the Kids Help Phone (Malik, 2020). Analyses are emerging of the potential effects of COVID-19 on organized crime, with reports suggesting a disruption in smuggling, and an increase in fraud and corruption in the health sector (Behar, 2020).

But there appears to be little foundation in social science for making a reliable assessment of the resilience of the social order in the face of such strain. Episodes of civil unrest have emerged after public health quarantines and curfews in countries with histories of violence and political tension (Madhav et al., 2017), but social science research tells us little about what we might expect elsewhere. A recent public health analysis concludes that "we know relatively little about population behaviour in serious pandemic situations" (Balinska \& Rizzo, 2009).

Research in social psychology indicates that in this vacuum of being unable to anticipate civil disobedience, what matters are the ideas of intervention that police, politicians, and others rely on-including the degree of coercion that police choose to deploy, or the degree to which they emphasize well-being. These then have effects on social behaviour (Drury, Novelli, \& Stott, 2013).

In addition to our own conversations with police leaders, there are ample signs in the media that police and political leaders are aware of this insight and trying to shape perceptions. The police are being thrust into the public health effort as a threat, rather than an enabler of positive social behaviour. On 26 March 2020, Prime Minister Trudeau announced to Canadians that "if you do not comply with these instructions, you could face serious fines and even prison time." In the United States, police in Rhode Island announced profiling protocols to enforce quarantine by stopping cars with $\mathrm{New}$ York license plates. In Israel, police are focused on explaining physical distancing but are also issuing tickets and requiring individuals to document why they are outside of their homes. And in Brazil, gangs have ordered favela residents to stay home or risk being "punished" (Breiner, 2020; Briso \& Phillips, 2020; McCausland, 2020; Trudeau, 2020).

Though their operations have rapidly changed, police agencies appear to have largely resisted a public expansion of their role and understood these exhortations to be a symbolic invocation of their authority rather than a call to action. There have been few arrests. Some agencies acknowledge that 
punitive enforcement of ordinances is still "hypothetical;" a Montreal police inspector affirmed that "the instructions that have been given to our police officers are that this is a tool to be used as an extreme last resort" (Gatehouse, 2020). It appears that the public subordination of policing activity to public health strategies is at times awkward for police. Some in the United States are clumsily beseeching people to desist from crime - as if it were an act of physical distancing: "We will let you know when you can return to your normal criminal behavior," one police department advised. Another announced in an awkward attempt at humour that they will update "when we deem it's appropriate to proceed with yo bad selves" (Coleman, 2020).

Other police agencies have expressed worry for their own officers as well as for the future of police-resident relations if the police operate in an overly aggressive manner when dealing with community well-being. "You can't exercise social distancing when you're taking police action," one chief said (Elinson \& Chapman, 2020). And a spokesperson for the Chicago Police Department said that while they are enforcing a directive to shelter in place, they are "not looking to arrest the entire city of Chicago," and while "we've got to contain it, [...] [w] are not trying to make this a police issue. This is very much a public health issue" (Schuba, 2020).

Yet other police departments are enthusiastically trying on the discourse of public health and seem to be thinking through what its precepts could mean for their professional role and identity. One example comes from the Israeli police, which has taken on the very language of public health to rethink policing: "Anyone who understands law enforcement," a senior officer reports, "knows that without administrative or criminal sanctions when appropriate and at the right dosage, there will be no deterrence or obedience or compliance with rules that were designed to protect the lives of all of us" (Breiner, 2020). Others, in private conversations, tell us that they are working with new partners in public health-and are excited about the possibilities for enhancing community safety as a result.

These examples do not cover the full spectrum of responses. Yet they provide an early indication of the range. Administrative data from police agencies would provide an indicator of how pandemic policing has also had effects for police operations.

Yet policing will also need to change again, as recovery from COVID-19 evolves. Many international organizations predict extreme economic consequences. The World Bank is advising of an "unprecedented shock." In Canada, Michael Sabia (2020) cautions that we are in "uncharted territory" since countries have "essentially shut down their economies." This too will require new police practices, measurements, and leadership strategies.

That said, if police alliances with health are occurring now, we know very little about what a police role and mandate should be in helping to foster a pandemic recovery, and about what questions of safety and security may emerge during that effort. Some criminologists claim that violent crime tends to increase after large-scale shocks such as war (Gartner \& Kennedy, 2018), and theories invoked to explain this observation-including trauma, economic instability, the rise of illicit economies, and the loss of political legitimacy of state officials during wartime-may be analogous to the struggle to the COVID-19 economic recovery. While findings on crime during the Great Depression are the subject of dispute (Sellin, 1937; Huzel, 1986), economic uncertainty, inequality, unemployment, and distrust of law enforcement agencies are all causally linked to crime and community disorder-and are further linked with negative health outcomes (Sampson, 2012). To what signs of distress and disorder will politicians and police leaders respond first and with greater force?

There are existing if underused models for policing that may resonate with future-oriented public health and economic needs-and some of these focus as much (or more) on social investment and inclusion as on incident response and risk reduction. These ideas of social investment have been identified in Canadian policing as "community safety and well-being," with leadership in Ontario, and attracting the attention of police leaders worldwide. The premise is that rather than incident response, policing should be enmeshed with health care, social services, and education-with the measurements for success in police leadership tied to identifying and responding to service gaps of communities, including poverty, youth services, and mental health needs (Hawkes, 2016). These data- and partnership-driven approaches to integrate policing into a larger system of service providers may be uniquely suited to pandemic policing and economic and social recovery, when we can anticipate significant economic insecurity, social dislocation, and uncertainty over the future.

\section{CONCLUSION}

Albert Camus's (1947) novel on the cholera epidemic implied that social disruption and disorder would be greatest just as the health epidemic ended. A thorough recovery from the pandemic might require a genuine reconsideration of the role of the police in the production of both community safety and social order. Police leaders know they need to work differently during the COVID-19 pandemic and its recovery, and are innovating to do so-and they can benefit from research to support these police reforms. Yet police, public health experts, and elected officials also have little guidance on how to work together to facilitate the economic and social recovery. Collaborative research along these lines can help devise potential strategies, prompted by the COVID-19 pandemic and its effects, to achieve these goals and produce well-being.

\section{CONFLICT OF INTEREST DISCLOSURES}

The authors declare that there are no conflicts of interest.

\section{AUTHOR AFFILIATIONS}

*Munk School of Global Affairs \& Public Policy and Department of Sociology, University of Toronto; ${ }^{\dagger}$ Munk School of Global Affairs \& Public Policy, University of Toronto.

\footnotetext{
REFERENCES

Balinska, M., \& Rizzo, C. (2009). Behavioural responses to influenza pandemics: what do we know? PLOS Currents, I, RRN1037.

Behar, R. (2020). Organized crime in the time of corona. Forbes. Retrieved from https://www.forbes.com/sites/richardbehar/2020/03/27/ organized-crime-in-the-time-of-corona/\#4a144d80150d
} 
Breiner, J. (2020). With coronavirus emergency rules still ill-defined, police moves to enforcement. Haaretz. Retrieved from https://www.haaretz. com/israel-news/.premium-with-coronavirus-emergency-rules-still-illdefined-police-moves-to-enforcement-1.8715340

Briscese, M., Lacetera, N., Macis, M., \& Tonim, M. (2020). Compliance with COVID-19 social-distancing measures in Italy: the role of expectations and duration. NBER Working Paper No. 26916.

Briso, C. B., \& Phillips, T. (2020). Brazil gangs impose strict curfews to slow coronavirus spread. The Guardian. Retrieved from https://www.the guardian.com/world/2020/mar/25/brazil-rio-gangs-coronavirus

Campeau, H., Levi, R., \& Foglesong, T. (2020). Policing, recognition, and the bind of legal cynicism. Forthcoming, Social Problems.

Camus, A. (1947). The plague. New York: Modern Library.

Carlson, J. (2020). Policing a pandemic. Retrieved from https://jdawncarlson.com/

Coleman, J. (2020). Police nationwide ask criminals to halt activity during coronavirus outbreak. The Hill. Retrieved from https:// thehill.com/policy/healthcare/public-global-health/487984 police-nationwide-ask-criminals-to-halt-activity

Desmond, M., Papachristos, A. V., \& Kirk, D. (2016). Police violence and citizen crime reporting in the black community. American Sociological Review, 81, 857-876.

Drury, J., Novelli D., \& Stott C. (2013). Representing crowd behaviour in emergency planning guidance: 'mass panic' or collective resilience? Resilience, 18-37.

Elinson, Z., \& Chapman B. (2020). Coronavirus pandemic changes policing, including fewer arrests. Wall Street Journal. Retrieved from https://www.wsj.com/articles/coronavirus-pandemic-changespolicing-including-fewer-arrests-11585301402

Gartner, R., \& Kennedy, L. (2018). War and postwar violence. Crime and Justice, 47, 1-67.

Gatehouse, J. (2020). "An extreme last resort": Police reluctant to ticket, arrest COVID-19 rule-breakers. CBC. Retrieved from https:// www.cbc.ca/news/investigates/police-covid-enforcement-finesarrests-1.5508144

Hagan, J., McCarthy, B., Herdad, D., \& Chandrasekhere, A. (2018). Dual-process theory of racial isolation, legal cynicism, and reported crime. Proceedings of the National Academy of Sciences, 115(28), 7190-7199.
Hawkes, J. V. N. (2016). Mobilizing and engaging your community to reduce victimization and reinvest police resources. Journal of Community Safety and Well-Being, 1(2), 21-25.

Huzel, J. P. (1986). The incidence of crime in Vancouver during the great depression. BC Studies, 69/70, 211-248.

Koehler, J. (2020). COVID-19 recasts criminal justice reforms once deemed 'unthinkable'. London School of Economics. Retrieved from https:// blogs.Ise.ac.uk/socialpolicy/2020/03/31/covid-19-recasts-criminaljustice-reforms-once-deemed-unthinkable/

Madhav, N., Oppenheim, B., Gallivan, M., Mulembakani, P., Rubin, E., \& Wolfe, N. (2017). Pandemics: risks, impacts, and mitigation. In D. T. Jamison, H. Gelband, S. Horton, P. Jha, R. Laxminarayan, C. N. Mock, \& R. Nugent (Eds.), Disease control priorities: improving health and reducing poverty (pp. 315-346). Washington, DC: The International Bank for Reconstruction and Development / The World Bank.

Malik, A. (2020). Trudeau announces $\$ 7.5$ million for Kids Help Phone amid COVID-19. Mobilesyrup. Retrieved from https://mobilesyrup. com/2020/03/29/trudeau-7-5-million-investment-kids-help-phonecovid-19/

McCausland, P. (2020). Rhode Island police, troops stopping incoming New Yorkers to force quarantine. NBC. Retrieved from https://www. nbcnews.com/news/us-news/rhode-island-police-troops-stoppingincoming-new-yorkers-force-quarantine-n 1171106

Sabia, M. (2020). In this pandemic, governments will face three tests-including how best to restart the economy. The Globe and Mail. Retrieved from https://www.theglobeandmail.com/business/commentary/ article-in-this-pandemic-governments-will-face-three-tests-including-how/

Sampson, R. (2012). Great American city: Chicago and the enduring neighborhood effect. Chicago, $\mathrm{OH}$ : University of Chicago Press.

Schuba, T. (2020). As life in Chicago largely comes to a halt, shootings continue on South, West sides. Chicago Sun Times. Retrieved from https://chicago.suntimes.com/crime/2020/3/22/21190076/shootings-chicago-murder-cpd-chicago-police-department-coronavirus-crime

Sellin, J. (1937). Research memorandum on crime in the depression. Social Science Research Council.

Stein, J. G., \& Levi, R. (2014). The social psychology of denial: deterring terrorism. Journal of International Law \& Politics, 47, 409-438.

Trudeau, J. (2020). Updating Canadians on the COVID-19 situation. 26 March 2020 